\title{
TWO-STAGE ALKALINE AND ACID PRETREATMENT APPLIED TO SUGARCANE BAGASSE TO ENRICH THE CELLULOSIC FRACTION AND IMPROVE ENZYMATIC DIGESTIBILITY
}

\author{
Longinus Ifeanyi Igbojionu ${ }^{1, *}$, Cecilia Laluce ${ }^{1}$ and Edison Pecoraro ${ }^{2}$
}

${ }^{1}$ Institute of Research in Bioenergy (IPBEN), Institute of Chemistry, São Paulo State University (UNESP), Rua Prof. Francisco Degni, 55, CEP 14800-060, Araraquara, São Paulo, Brazil

2 Department of General and Inorganic Chemistry, Institute of Chemistry, São Paulo State University (UNESP), Rua Professor Francisco Degni, 55, CEP 14800-060, Araraquara, São Paulo, Brazil

Article Info:

Received:

5 November 2019

Revised:

6 April 2020

Accepted:

5 June 2020

Available online:

7 September 2020

Keywords:

Sugarcane bagasse

Two-stage pretreatment

Acid pretreatment

Cellulosic fraction

Saccharomyces cerevisiae

(IQAr/45-1)

Enzymatic hydrolysis

\section{ABSTRACT}

Sugarcane bagasse (SB) is made up of cellulose (32-43\%), hemicellulose (19-34\%) and lignin $(14-30 \%)$. Due to high recalcitrant nature of SB, pretreatment is required to deconstruct its structure and enrich the cellulosic fraction. A two-stage $\mathrm{NaOH}$ and maleic acid pretreatment was applied to SB to enrich its cellulosic fraction. SB used in the present study is composed of cellulose (40.4 wt\%), hemicellulose (20.9 $w t \%)$, lignin (22.5 wt\%) and ash (4.0 wt\%). After one-stage $\mathrm{NaOH}$ pretreatment, its cellulosic fraction increased to $61.8 \mathrm{wt} \%$ and later increased to $80.1 \mathrm{wt} \%$ after the second-stage acid pretreatment. Lignin fraction decreased to $3.0 \mathrm{wt} \%$ after onestage $\mathrm{NaOH}$ pretreatment and remained unaffected after the acid pretreatment step. Hemicellulose fraction decreased substantially after the second-stage pretreatment with maleic acid. Pretreated SB displayed high crystallinity index and improved enzymatic digestibility. Hydrolysates of pretreated SB contained very low amount of $x y-$ lose and subsequent fermentation by Saccharomyces cerevisiae -IQAr/45-1 resulted to ethanol level of $8.94 \mathrm{~g} / \mathrm{L}$. Maximal ethanol yield of $0.49 \mathrm{~g} / \mathrm{g}(95.8 \%$ of theoretical yield) and productivity of $0.28 \mathrm{~g} / \mathrm{L} / \mathrm{h}$ was attained. At the same time, biomass yield and productivity of $0.47 \mathrm{~g} / \mathrm{g}$ and $0.27 \mathrm{~g} / \mathrm{L} / \mathrm{h}$ respectively were obtained. Two-stage $\mathrm{NaOH}$ and maleic acid pretreatment led to $\sim$ two-fold increase in cellulosic fraction and enhanced the enzymatic digestibility of SB up to $70.4 \%$. The resulted enzymatic hydrolysate was efficiently utilized by $S$. cerevisiae -IQAr/45-1 to produce high yield of ethanol. Thus, optimization of enzymatic hydrolysis at low enzyme loading is expected to further improve the process and reduce cost.

\section{INTRODUCTION}

Sugarcane bagasse (SB) is an important feedstock for second generation bioethanol production due to its large abundance, non-competitiveness with food or feed requirement, easy transportation and rich in accessible carbohydrates (Singh et al. 2015; Chandel et al., 2012). The composition and productivity of bagasse is dependent on sugarcane variety, climate, location, plant age, and soil types (Zhao and Li, 2015). SB is made up of cellulose (32$43 \%)$, hemicellulose (19-34\%) and lignin (14-30\%) (Brienzo et al., 2016; Timung et al., 2016).

Cellulose exists as D-glucose subunits, linked by $\beta-1,4$ glycosidic bonds (Jönsson et al., 2016) and its microfibrils are chemically bound to lignin and hemicellulose (Zhang et al., 2016). The cellulose in a plant consists of parts with a crystalline (organized) structure, and parts with not well-or- ganized, amorphous structure (Rongpipi et al., 2019).

Hemicelluloses, unlike cellulose, are polymers constituted of heterogeneous, branched polysaccharide composed of $\mathrm{C}_{5}$ sugars (xylose, arabinose) and $\mathrm{C}_{6}$ sugars (mannose, glucose and galactose), which serve as a connection between lignin and the cellulose fibers (Lee et al., 2014). Xylan is a dominant component of hemicellulose from hardwood and agricultural plants, such as grasses and straw while for softwood it is glucomannan (Álvarez et al., 2016). Lignin is a complex, cross-linked, three-dimensional polymers of phenolic monomers having both aliphatic and aromatic constituents (Karunarathna and Smith, 2020). Lignin is a constituent that is known to inhibit enzymatic saccharification and fermentative microorganisms (Kucharska et al., 2020). Nevertheless, the matrix structure of lignocellulosic biomass prevents the enzymatic saccharifcation and subsequently sugars fermentation to bioeth- 
anol (Sun et al., 2015). Thus, pretreatment is required to deconstruct the intact structure by removal of hemicellulose/lignin and improve the enzyme accessibility to cellulose (Isaac et al., 2018; Acharjee et al., 2017). On the other hand, pretreatment can only be considered effective if it minimizes carbohydrate degradation and the production of enzyme inhibitors as well as toxic products for fermenting microorganisms (Thite et al., 2019; Laluce et al., 2019a).

Research activities in the last few years have been directed towards improving sugar yield from lignocellulosic biomass through the application of physical, chemical, physicochemical and biological pretreatments (Mohapatra et al., 2017). Chemical pretreatments with dilute inorganic acids and alkali have been applied to hydrolyze lignocellulosic biomass (Laluce et al., 2019b; Matsakas et al., 2018; Silveira et al., 2015). On the other hand, dicarboxylic organic acids such as maleic acid are considered alternative to inorganic acids (e.g. sulfuric acid) because they have lower hazardous properties and lower inhibitory by-products generation as well as the ability to hydrolyze $\beta-(1,4)$ glycosidic bonds (Girolamo et al., 2016; Jung et al., 2014). Maleic acid pretreatment of oil palm trunk was reported to effectively remove hemicellulose and part of acid soluble lignin (Qiao et. at. 2019).

The combinations of delignification process with dilute acid pretreatment have been applied to remove lignin and solubilize most of the hemicellulose sugars from SB (Zhang et al., 2018; Chandel et al., 2014). However, pretreatment combining $\mathrm{NaOH}$ pretreatment (first-stage) and maleic acid pretreatment (second-stage) is scarcely reported in the literature.

Thus, a two-stage pretreatment of SB was proposed in this study to degrade lignin using $3.0 \% \mathrm{NaOH}$ at $121^{\circ} \mathrm{C}$ for $60 \mathrm{~min}$ in the first-stage and then to solubilize hemicellulose using $0.3 \%$ maleic pretreatment at $121^{\circ} \mathrm{C}$ for 60 min in the second-stage. Subsequently, the one-stage and two-stage pretreated SB was characterized by chemical constituent analysis and X-ray diffraction (XRD) was used to investigate the structural changes that occurred during pretreatments. Furthermore, enzymatic saccharification of pretreated SB and ethanol fermentation performance by Saccharomyces cerevisiae (IQAr/45-1) were evaluated.

\section{EXPERIMENTAL}

\subsection{Sample preparation and processing}

Sugarcane bagasse was collected from a local sugar mill plant, Santa Cruz (member of São Martinho group) located in Américo Brasiliense, São Paulo, Brazil and transported at low temperature. Bagasse was stored in a laboratory freezer at $-20^{\circ} \mathrm{C}$. Frozen samples were defrosted and dried at $60^{\circ} \mathrm{C}$ in a laboratory incubator until a constant weight was obtained ( $<10 \% \mathrm{wt}$, moisture). Dry bagasse samples were stored in transparent plastic bags at room temperature before use.

Milling the dry sugarcane bagasse (SB) by a physical method initiated the degradation of lignocellulose and conversion of the biomass fibers into particles, thereby increasing biomass surface area (Palmowski and Müller, 2000). For this, sugarcane bagasse was ground for 15 min/cycle in Marconi Ball Mill with Closed Chamber (model MA350) to obtain particles of $\leq 0.5 \mathrm{~mm}$ after passing through a set of superposed sieves of different meshes $(32,35$, and 150 mesh).

Subsequently, SB was refluxed in a Soxhlet extraction apparatus containing a mixture of toluene:ethanol (2:1, v/v) (Sun et al., 2004). The sample was refluxed in water for $30 \mathrm{~min}$ to remove the remaining solvents before being dried in a Biochemical Oxygen Demand (BOD) incubator, as recommended in the literature (Binod et al., 2012) at $60^{\circ} \mathrm{C}$ to constant weight before being stored in a desiccator at room temperature until use.

\subsection{Pretreatment with alkaline solution (one-stage)}

Dry sugarcane bagasse (particle size $\leq 0.5 \mathrm{~mm}$ ) was treated with different concentrations of $\mathrm{NaOH}$ solution $(0.5 \%-3 \%, \mathrm{w} / \mathrm{v})$ in $125 \mathrm{ml}$ Erlenmeyer flasks at solid/liquid ratio of $1: 20$. Flasks were gently swirled to enable the solid to become completely soaked in the solution before been transferred into the autoclave and heated for 60 minutes at $121^{\circ} \mathrm{C}$. After heating, samples were removed from the autoclave and allowed to cool before filtration under vacuum using Whatman No. 1 filter papers.

Filtrate was collected and used to assay for glucose and xylose while the insoluble material (residues) on the filter paper was washed several times with deionized water to neutral $\mathrm{pH}$ and dried at $60^{\circ} \mathrm{C}$ to a constant weight. Dry residues were used for compositional analysis and dilute acid pretreatment step.

\subsection{Selection of optimum condition for acid pretre- atment step}

Dilute acid solutions of maleic acid (MA) in the range of $0.1 \%-0.5 \%(\mathrm{~W} / \mathrm{v})$ were used to hydrolyze sugarcane bagasse at $121^{\circ} \mathrm{C}$ (autoclave) for 60 minutes with solid/liquid ratio of 1:20. Sample was removed after autoclaving and allowed to cool on ice bath and filtered under vacuum using Whatman No. 1 filter papers. Filtrate was collected and used to measure the soluble reducing sugars (SRS) using 3,5-Dinitrosalicylic acid (DNS) reagent. The residue on the filter paper was washed with deionized water to neutral $\mathrm{pH}$ and dried in a hot air oven at $60^{\circ} \mathrm{C}$ till the weight remained constant and measured. The lowest concentration of acid that yielded the highest amount of SRS and highest biomass loss_was selected for the second step pretreatment.

The amount of released SRS in pretreatment filtrate from SCB was measured using D-glucose as standard and expressed as \% released SRS as mentioned below.

$$
\begin{aligned}
& \% \text { released } S R S= \\
& =\frac{\text { reducing sugar released in filtrate during pretreatment }(\mathrm{mg})}{\text { biomass used for pretreatment }(\mathrm{mg})} \times 100
\end{aligned}
$$

Decrease in weight of dry biomass was calculated as mentioned below and expressed as \% weight loss in biomass.

$\%$ weight loss in biomass $=\frac{\text { biomass obtained after drying }(\mathrm{mg})}{\text { biomass used for pretreatment }(\mathrm{mg})} \times 100$

\subsection{Two-stage alkaline and acid pretreatments}

Dry residues which originated from the one-stage pretreatment with different concentrations of $\mathrm{NaOH}$ were sus- 
pended in dilute solution of maleic acid $(0.3 \%, \mathrm{w} / \mathrm{v})$ in 125 $\mathrm{ml}$ Erlenmeyer flask at solid/liquid ratio of $1: 20$. Flasks were placed in autoclave and heated for 60 minutes at $121^{\circ} \mathrm{C}$. Thereafter, flasks were removed and allowed to cool before filtration. Filtrate was collected and used to assay for glucose and xylose, while the residues on the filter paper was washed several times with deionized water to neutral $\mathrm{pH}$ before been dried in $\mathrm{BOD}$ at $60^{\circ} \mathrm{C}$ to a constant weight and used for chemical composition analysis.

\subsection{Determination of the chemical composition of untreated SB and pretreated fractions}

The chemical components of untreated and pretreated SB were analyzed using the method described by National Renewable Energy Laboratory (Sluiter et al., 2008). 300 mg dry residues resulting from pretreatment or untreated SB was weighed into a pressure glass tube and $3.0 \mathrm{ml}$ of $72 \%$ sulfuric acid was added, the mixture was stirred with glass rod and tube was place in water bath at $30^{\circ} \mathrm{C}$ for $1 \mathrm{~h}$. The mixture was stirred while in water bath at every $10 \mathrm{~min}$. After $1 \mathrm{~h}$ of hydrolysis, tube was removed from water bath and $84 \mathrm{ml}$ of deionized water was added to bring the acid concentration to $4 \%$. The tube was covered and inverted several times to allow sample to mix and autoclaved at $121^{\circ} \mathrm{C}$ for $1 \mathrm{~h}$.

After autoclaving, the mixture was cooled down to room temperature and separated into solid and liquid fractions by vacuum filtration using Whatman No.1 filter papers. Solid fraction was then dried at $105^{\circ} \mathrm{C}$ in order to measure acid insoluble residue (AIR). Acid insoluble residue was burnt in muffle furnace at $600^{\circ} \mathrm{C}$ for about $6 \mathrm{~h}$ to measure acid insoluble lignin (AIL) content as the difference between AIR and ash. Before neutralization, the absorbance of liquid fraction at $240 \mathrm{~nm}$ was measured by UV-visible spectrophotometer (Cirrus 80 ST, Femto, São Paulo, Brazil) to determine acid soluble lignin (ASL). Liquid fraction was neutralized with calcium carbonate and the resulting filtrate was used to assay for glucose and xylose.

Glucose was assayed using a commercial enzymatic kit (GOD-PAP, Laborlab) and xylose by the phloroglucinol method using xylose as standard (Ebert et al., 1979). Total furans were estimated by a spectrophotometric method based on the difference in absorbance at 284 and $320 \mathrm{~nm}$ (Martinez et al., 2000) using a UV/Vis/NIR-spectrometer with a 3D WB Detector Module (Perkin Elmer, Inc., Shelton, CT USA). A standard curve was obtained for each assay by linear regression using the software OriginPro 8 from OriginLab Corporation.

\subsection{X-Ray Diffraction (XRD)}

XRD was used as a tool to investigate the structural changes that occurred during pretreatments of sugarcane bagasse. The crystalline structure of biomass is mainly due to the strong hydrogen bonding of cellulose chains and Vander Waals forces of glucose molecules in the cellulose (Naik et. al., 2010; Sasmal et. al., 2012).

The crystallinity of the cellulose fiber was evaluated by X-Ray Diffraction (Siemens D5000 diffractometer, Munich, Germany). Copper Karadiation, 30.0 kV of voltage and 15
$\mathrm{mA}$ of electric current, and a rate of 2.0 degrees per minute for a $2 \theta$ continuous scan from 5.0 to 50.0 degrees were applied. This analysis allowed the detection of the amorphous part of the lignocellulosic biomass, as well as the modification of the crystalline structure of the cellulose.

The crystallinity index $(\mathrm{Cl})$ was obtained from the ratio of the maximum peak intensity $002\left(\mathrm{I}_{002}, 2 \theta=22.5\right)$ and minimal depression $\left(\mathrm{I}_{\mathrm{am}} 2 \theta=18.5\right)$ between peaks 001 and 002 (Segal et al., 1959; Rodrigues et al., 2007) as mentioned below.

$C I(\%)=\frac{I_{002}-I_{a m}}{I_{002}} \times 100$

where $\mathrm{I}_{002}$ is the maximum intensity of the 002 peak and $\mathrm{I}_{\mathrm{am}}$ the minimal depression of the amorphous structure.

\subsection{Enzymatic hydrolysis}

Dry pretreated SB and untreated SB were each soaked in $50 \mathrm{mM}$ sodium citrate buffer ( $\mathrm{pH} \mathrm{4.8)}$ at solid loading of $5 \%(\mathrm{w} / \mathrm{v})$ in $125 \mathrm{ml}$ Erlenmeyer flask. Flask was placed in incubator (Tecnal TE-391, Piracicaba, SP, Brazil) and incubated for $2 \mathrm{~h}$ at $50^{\circ} \mathrm{C}$ with shaking speed of $150 \mathrm{rpm}$. Thereafter, the soaked sample was supplemented with $8.7 \mathrm{FPU} / \mathrm{g}$ dried sample of Cellulase from Trichoderma reesei, (Sigma Aldrich) and $5.6 \mathrm{IU} / \mathrm{g}$ dry sample of $\beta$-glucosidase (Sigma Aldrich). A dose of $0.005 \%$ sodium azide was introduced to avoid any microbial contamination and 1.0\% (v/v) Tween 80 was added to facilitate the enzymatic action. Enzymatic hydrolysis was performed at $50^{\circ} \mathrm{C}$ for $72 \mathrm{~h}$ with shaking at $150 \mathrm{rpm}$. Samples were withdrawn at 6 h, 12 h, 24 h, $48 \mathrm{~h}$ and $72 \mathrm{~h}$ intervals and enzymes were inactivated by boiling at $100^{\circ} \mathrm{C}$ for $10 \mathrm{~min}$ after which samples were cooled on ice before subsequently analyzed for glucose released using a commercial enzymatic kit (GOD-PAP, Laborlab).

Saccharification (\%) was calculated as mentioned below:

$$
\begin{aligned}
& \% \text { saccharification }= \\
& =\frac{\text { reducing sugar released by enzymatic hydrolysis }(\mathrm{mg})}{\text { initial solid biomass used for hydrolysis }(\mathrm{mg})} \times 100
\end{aligned}
$$

\subsection{Fermentation}

The Saccharomyces cerevisiae -IQAr/45-1 is a thermotolerant ethanologenic yeast strain obtained from the hybridization between parental strains of $S$. cerevisiae and three Brazilian industrial strains (PE-2, CAT-1, SA-1) during fermentation of non-sterilized molasses (Laluce et. al. 2013). This strain can only ferment hexose sugars and it was maintained in medium containing $(\mathrm{g} / \mathrm{L})$ : glucose, 30.0; yeast extract, 3.0; peptone, 5.0; agar, 20.0 at pH $6.0 \pm 0.2$ and temperature $30^{\circ} \mathrm{C}$. Starter culture was developed by growing the cells at $30^{\circ} \mathrm{C}$ for $24 \mathrm{~h}$ in a culture medium containing (g/L): glucose, 30.0; yeasts extract, 3.0; peptone, 5.0; $\mathrm{pH} 6.0 \pm 0.2$.

The fermentation of enzymatic hydrolysates of twostage $\mathrm{NaOH}+\mathrm{MA}$ pretreated $\mathrm{SB}(17.3 \mathrm{~g} / \mathrm{L}$ glucose, $\mathrm{pH} 6.0$ \pm 0.2 ) was carried out in $125 \mathrm{ml}$ Erlenmeyer flask with a working volume of $50 \mathrm{ml}$ supplemented with $3 \mathrm{~g} / \mathrm{L}$ of yeast extract and $5 \mathrm{~g} / \mathrm{L}$ of peptone. It was inoculated with $S$. cerevisiae $(10.0 \% \mathrm{v} / \mathrm{v})$ at optical density $\left(\mathrm{OD}_{600}\right)$ of 0.6 . Sample was incubated at $30^{\circ} \mathrm{C}$ for $30 \mathrm{~h}$ with shaking at $150 \mathrm{rpm}$. 
Samples were centrifuged at $10,000 \mathrm{~g}$ for $15 \mathrm{~min}$ at $4^{\circ} \mathrm{C}$ and the cell free supernatant was used to determine the ethanol and residual sugar concentration.

Cell concentrations were measured at optical density of $600 \mathrm{~nm}$ and related to the cell dry weight through a calibration curve. Ethanol was estimated using acidified potassium dichromate solution as described by Caputi et al., (1968).

Fermentation parameters were calculated as mentioned below:

$\mathrm{Y}_{\mathrm{P} / \mathrm{S}}=\frac{\mathrm{E}_{\mathrm{f}}-\mathrm{E}_{i}}{\left(\mathrm{~S}_{\mathrm{i}}-\mathrm{S}_{\mathrm{f}}\right)}$

$Y_{P / S}$ is the ethanol yield, $E_{i}$ and $E_{f}$ are the ethanol concentration at the beginning of the fermentation and the end of the fermentation $(\mathrm{g} / \mathrm{L})$ respectively; while $\mathrm{S}_{i}$ and $\mathrm{S}_{\mathrm{f}}$ are the total sugar concentration at the beginning of the fermentation and the end of the fermentation $(\mathrm{g} / \mathrm{L})$, respectively.

$\mathrm{Q}_{P_{P}}=\frac{\mathrm{E}_{\mathrm{f}-\mathrm{E}_{\mathrm{i}}}}{t_{f}-\mathrm{t}_{\mathrm{i}}}$

$Q_{P p}$ is the volumetric ethanol productivity $(g / L / h), E_{i}$ and $E_{f}$ are the ethanol concentration at the beginning and end of fermentation $(\mathrm{g} / \mathrm{L})$, respectively; while $t_{i}$ and $t_{f}$ are the fermentation time at the beginning of the fermentation and the end of the fermentation $(\mathrm{g} / \mathrm{L})$, respectively.

$Y_{X / S}=\frac{X_{f}-X_{i}}{S_{i}-S_{f}}$

$Y_{x / s}$ is the biomass yield $X_{i}$ and $X_{f}$ are the biomass concentration at the beginning of the fermentation and the end of the fermentation $(\mathrm{g} / \mathrm{L})$, respectively; while $S_{i}$ and $S_{f}$ are the total sugar concentration at the beginning of the fermentation and the end of the fermentation $(\mathrm{g} / \mathrm{L})$, respectively.

$\mathrm{Q}_{P_{X}}=\frac{\mathrm{x}_{\mathrm{f}-\mathrm{x}_{\mathrm{i}}}}{\mathrm{t}_{\mathrm{f}-\mathrm{t}_{\mathrm{I}}}}$

$\mathrm{Q}_{\mathrm{Px}}$ is the biomass productivity $(\mathrm{g} / \mathrm{L} / \mathrm{h}), \mathrm{X}_{\mathrm{i}}$ and $\mathrm{X}_{\mathrm{f}}$ are the biomass concentration at the beginning and end of fermentation $(\mathrm{g} / \mathrm{L})$, respectively; while $\mathrm{t}_{0}$ and $\mathrm{t}_{\mathrm{r}}$ are the fermentation time at the beginning of the fermentation and the end of the fermentation $(\mathrm{g} / \mathrm{L})$, respectively.

Fermentation efficiency $(\%)=\frac{\text { Actual Yield }}{\text { Theoretical Yield }} \times 100$

where theoretical yield is equivalent to $0.511 \mathrm{~g} / \mathrm{g}$.

\subsection{Data analysis}

The graphs were created using the software OriginPro 8 from OriginLab Corporation. Each data was expressed as a mean of standard deviation (SD) of triplicate measurements.

\section{RESULTS AND DISCUSSION}

\subsection{Pretreatments}

A preliminary study to select the optimal condition for acid pretreated step is presented in Table 1. One-stage maleic acid pretreatment of SB resulted to loss of dry weight ranging from $10.6 \%$ to $23.4 \%$, while the yield of SRS in the acid hydrolysate ranges from $8.5 \%$ to $10.6 \%$. The loss of dry weight was mainly attributed to hemicellulose solubilization during acid pretreatment (Baruah et al., 2018, Li et al., 2016). Thus, the yield of SRS and loss of dry weight were directly correlated with acid concentration. The mass differences between loss of dry weight and yield of SRS could be connected to the presence of other extractive components in the SB, which were solubilized during acid pretreatment.

Table 2 shows the results of one-stage $\mathrm{NaOH}$ and twostage $\mathrm{NaOH}$ and maleic acid pretreatments applied to SB. It was found that increases in $\mathrm{NaOH}$ concentration from $0.5 \%$ to $3.0 \%$ led to corresponding increases in cellulosic fractions of SB from $45.5 \mathrm{wt} \%$ to $61.8 \mathrm{wt} \%$. The proportionality observed between $\mathrm{NaOH}$ concentration and cellulosic fraction was due to lignin removal at increasing $\mathrm{NaOH}$ concentration. According to the literature, alkaline pretreatment can facilitate dissociation of entire cell wall polymers by breaking hydrogen and covalent bonds thereby enabling effective lignin removal (Thite et al., 2019; Rezende et al., 2011).

The second-stage pretreatment with $0.3 \%$ maleic acid led to increase in cellulosic fractions from 46.7 to 80.1 wt\%. This increase could be attributed to hemicellulose removal during the acid pretreatment step. Dilute acid pretreatments have been reported to cause hemicellulose solubilization and cellulose enrichment (Zhang et al., 2018; Rezende et al., 2011).

Interestingly, cellulosic fractions of SB resulting from two-stage $\mathrm{NaOH}$ and maleic acid pretreatments are connected to the cellulosic fractions from the first-stage $\mathrm{NaOH}$ pretreatment. This implies that the higher the cellulosic fraction after first-stage $\mathrm{NaOH}$ pretreatment, the higher the cellulosic fraction after the second-stage acid pretreatment. The correlations between first- and second-stage pretreatments were mainly due to hemicellulose solubilization during the second-stage acid pretreatment.

\subsection{Chemical composition of untreated (raw) and pretreated sugarcane bagasse.}

SB used in the present study consists of $~ 10 \%$ moisture and particle size of about $0.50 \mathrm{~mm}$. Its chemical composition is made up of cellulose (40.4 wt\%), hemicellulose (20.9 wt\%), lignin (22.5 wt\%) and ash (4.0 wt\%) as shown in Table 3. These values are similar to those reported by other authors (Rabelo et al., 2009; Sporck et al., 2017). Furthermore, chemical composition and productivity of SB are mostly dependent on sugarcane variety, climate, location, plant age and soil types (Zhao and Li, 2015).

TABLE 1: Effect of maleic acid concentration on the release of soluble reducing sugars (\%) in pretreatment filtrate and loss of dry weight (\%) during the pretreatment of sugarcane bagasse in autoclave $\left(121^{\circ} \mathrm{C}\right)$ for $60 \mathrm{~min}$.

\begin{tabular}{c|c:c|c|c}
\hline $\begin{array}{c}\text { Maleic acid } \\
(\%, \mathbf{w} / \mathbf{v})\end{array}$ & $\begin{array}{c}\text { Temperature } \\
\left({ }^{\circ} \mathbf{C}\right)\end{array}$ & $\begin{array}{c}\text { Time } \\
(\mathbf{m i n})\end{array}$ & $\begin{array}{c}\text { Soluble reduc- } \\
\text { ing sugars (\%) }\end{array}$ & $\begin{array}{c}\text { Loss of dry } \\
\text { weight (\%) }\end{array}$ \\
\hline 0.1 & 121 & 60 & $8.5 \pm 0.4$ & $10.6 \pm 0.4$ \\
\hline 0.2 & & $10.0 \pm 0.6$ & $13.5 \pm 0.6$ \\
\hline 0.3 & & $15.6 \pm 0.3$ & $19.1 \pm 0.5$ \\
\hline 0.4 & & & $16.9 \pm 1.2$ & $20.0 \pm 0.3$ \\
\hline 0.5 & & & $19.2 \pm 1.1$ & $21.9 \pm 0.4$ \\
\hline 0.6 & & & $20.8 \pm 0.7$ & $23.4 \pm 0.5$ \\
\hline
\end{tabular}


TABLE 2: Cellulosic fractions resulting from first-stage $\mathrm{NaOH}$ pretreatment and second-stage pretreatment with $0.3 \%$ maleic acid in autoclave.

\begin{tabular}{|c|c|c|c|c|c|c|c|}
\hline \multicolumn{8}{|c|}{ Pretreatment } \\
\hline \multicolumn{4}{|c|}{ First-stage } & \multicolumn{4}{|c|}{ Second-stage } \\
\hline $\mathrm{NaOH}(\%, w / v)$ & Temp $\left({ }^{\circ} \mathrm{C}\right)$ & Time $(\min )$ & Cellulose (wt\%) & Acid (w/v) & Temp $\left({ }^{\circ} \mathrm{C}\right)$ & Time (min) & Cellulose (wt\%) \\
\hline 0.0 & 121 & 60 & $42.7 \pm 0.6$ & $0.3 \% \mathrm{MA}$ & 121 & 60 & $46.7 \pm 0.7$ \\
\hline 0.5 & & & $45.5 \pm 0.6$ & & & & $56.5 \pm 1.5$ \\
\hline 1.0 & & & $48.9 \pm 1.0$ & & & & $63.0 \pm 1.4$ \\
\hline 1.5 & & & $55.5 \pm 1.0$ & & & & $68.7 \pm 1.2$ \\
\hline 2.0 & & & $58.4 \pm 0.3$ & & & & $73.8 \pm 1.2$ \\
\hline 2.5 & & & $59.8 \pm 0.8$ & & & & $78.7 \pm 0.9$ \\
\hline 3.0 & & & $61.8 \pm 1.3$ & & & & $80.1 \pm 1.8$ \\
\hline
\end{tabular}

TABLE 3: Chemical composition of solid fractions of untreated and pretreated sugarcane bagasse and composition of pretreatment hydrolysates.

\begin{tabular}{|c|c|c|c|c|c|c|}
\hline \multirow{2}{*}{$\begin{array}{l}\text { Pretreatment } \\
(60 \mathrm{~min}, \\
\left.121^{\circ} \mathrm{C}\right)\end{array}$} & \multicolumn{4}{|c|}{ Chemical composition of dry solid fraction } & \multicolumn{2}{|c|}{ Constituents of pretreatment filtrate } \\
\hline & Cellulose (wt\%) & Hemicellulose (wt\%) & Lignin (wt\%) & Ash (wt\%) & Xylose $e^{\#}(\%, g / g)$ & Total furans $(\mathrm{mg} / \mathrm{L})$ \\
\hline Untreated SB & $40.4 \pm 0.9$ & $20.9 \pm 0.7$ & $22.5 \pm 0.4$ & $4.0 \pm 0.0$ & na* & na* \\
\hline $3 \% \mathrm{NaOH}$ & $61.8 \pm 1.3$ & $17.6 \pm 0.5$ & $3.0 \pm 0.1$ & $2.7 \pm 0.1$ & $20.7 \pm 1.8$ & na* \\
\hline $\begin{array}{l}3 \% \mathrm{NaOH} \\
+0.3 \% \mathrm{MA}\end{array}$ & $80.1 \pm 1.8$ & $4.0 \pm 0.5$ & $3.7 \pm 0.1$ & $1.9 \pm 0.2$ & $40.0 \pm 1.1$ & $20.6 \pm 0.7$ \\
\hline
\end{tabular}

"Xylose, ( $\left.g / g_{\text {hemicellulose }}\right)$; na, not analyzed

Chemical composition of SB varied significantly after pretreatments were applied. Based on the cellulosic fractions obtained after pretreatment, one-stage $\mathrm{NaOH}(3 \%$ $\mathrm{NaOH})$ pretreated SB showed appreciable increase in cellulosic fraction (61.8 wt\%) compared to untreated SB (40.4 wt\%), while its hemicellulose and lignin fractions decreased to $17.6 \mathrm{wt} \%$ and $3.0 \mathrm{wt} \%$ respectively. Similarly, the second-stage pretreatment with $0.3 \%$ maleic acid showed much significant increase in cellulosic fraction (80.1 wt\%), while hemicellulose and lignin fractions decreased to 4.0 $w t \%$ and $3.7 \mathrm{wt} \%$ respectively. Thus, lignin removal from SB was mainly attributed to $\mathrm{NaOH}$ pretreatment step. Delignification of SB by alkaline pretreatments has been reported in the literature (Zhang et al., 2018). Concerning the ash content, one-stage $\mathrm{NaOH}$ pretreatment led to significant decrease in ash content (2.7 wt\%), while no significant effect on the ash content was obtained after second-stage pretreatment with maleic acid.

Alkaline pretreatment of $\mathrm{SB}$ using $\mathrm{NaOH}$ led to the removal of major part of lignin fraction with the retention of cellulose and hemicellulose fractions. Conversely, maleic acid pretreatment removed major part of hemicellulose and acid soluble fraction of lignin, while the cellulosic components and insoluble lignin remained largely unaffected. However, pretreatment filtrates from first-stage pretreatment with $3 \% \mathrm{NaOH}$ and second-stage pretreatment with $0.3 \%$ maleic acid contain significant amount of xylose. This suggests that part of hemicellulose was solubilized during both the first-stage $\mathrm{NaOH}$ and second-stage maleic acid pretreatments. Furthermore, filtrates from the secondstage maleic acid pretreatment were found to contain very low amount of total furans $(20.6 \mathrm{mg} / \mathrm{L})$. The low amount of total furans obtained in this study emphasizes the main benefit associated with the use of organic acid such as maleic acid for pretreatment of SB.

\subsection{XRD analysis of untreated (raw) and pretreated SB biomass}

Lignocellulose crystallinity could be transformed via pretreatment by opening crystal hydrogen bonding, degrading amorphous constituents and increasing crystal regions, thereby affecting subsequent enzymatic saccharification (Zhang et al., 2018). Thus, the XRD patterns and $\mathrm{Cl}$ of untreated and pretreated SB were investigated and the results are as shown in Figure 1. The $\mathrm{Cl}$ of untreated SB was $55.2 \%$ and after pretreatment with $3.0 \% \mathrm{NaOH}, \mathrm{Cl}$ increased to $69.0 \%$, while a higher $\mathrm{Cl}$ of $79.2 \%$ resulted from the combination of $\mathrm{NaOH}$ and maleic acid pretreatment steps.

However, all the pretreated SB presented higher Cls than the control (raw material). This phenomenon was mainly due to the removal of amorphous hemicellulose and lignin. The highest $\mathrm{Cl}$ value indicates greater removal of hemicelluloses, leaving the crystalline cellulose fraction intact in the pretreated solid residues (Timung et al., 2016). Hence, crystallinity of cellulose was found to increase after pretreatments were applied to SB, mainly due to the increase in cellulose content (Rezende et al., 2011). The $\mathrm{Cl}$ was found to correlate with the result of chemical composition analysis.

\subsection{Studies on amenability of the pretreated bio- mass to enzymatic hydrolysis}

In the literature, plenty of reports are available showing cellulose conversion rates of variedly pretreated lignocellulosic biomass after subjecting them to enzymatic hydrolysis. 


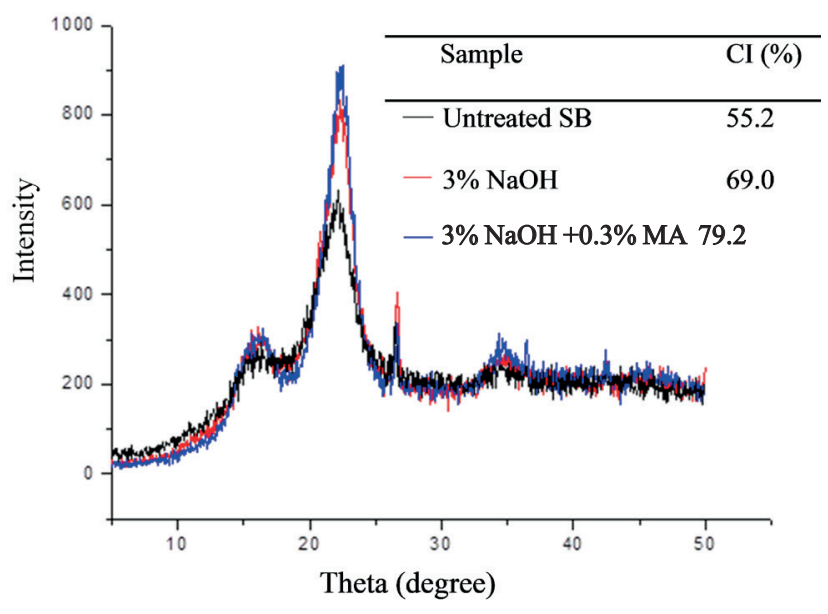

FIGURE 1: Diffractograms and crystallinity index $(\mathrm{CI})$ of untreated SB and solid fractions resulting from pretreatment with $3.0 \%$ $\mathrm{NaOH}$ (one-stage pretreatment) and $3.0 \% \mathrm{NaOH}+0.3 \% \mathrm{MA}$ (onestage $\mathrm{NaOH}$ pretreatment followed by the second-stage maleic acid pretreatment) respectively.

Few of them are listed and compared with the results in the present study (Table 4). The lowest conversion rate of $12.9 \%$ was obtained from untreated SB (raw material), while the highest conversion rate of $70.4 \%$ was obtained from SB emanating from two-stage $\mathrm{NaOH}$ and maleic acid pretreatments. The conversion rate of SB (60.2\%) emanating from first-stage $\mathrm{NaOH}$ pretreatment was significantly higher than the untreated SB. This suggests that the firststage pretreatment with $3 \% \mathrm{NaOH}$ effectively remove lignin from SB, thereby improving its enzymatic digestibility. On the other hand, the second-stage pretreatment with $0.3 \%$ maleic acid was able to remove greater part of hemicellulose, which further enhanced enzymatic digestibility of SB.

The presence of lignin and hemicellulose negatively affects enzymatic hydrolysis by binding to cellulose, thereby impeding its access to cellulose (Zheng et al., 2018; Sabanci et al., 2018). Therefore, the lowest conversion rate

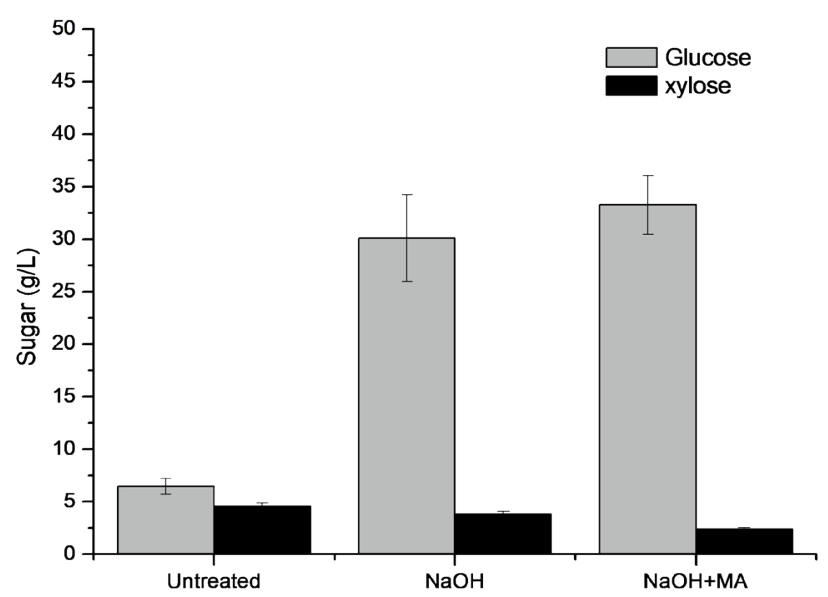

FIGURE 2: Xylose and glucose concentration after $72 \mathrm{~h}$ of enzymatic hydrolysis of untreated SB and solid fractions resulting from pretreatment of SB with $3.0 \% \mathrm{NaOH}$ (one-stage pretreatment) and $3.0 \% \mathrm{NaOH}+0.3 \%$ maleic acid (one-stage $\mathrm{NaOH}$ pretreatment followed by the second-stage maleic acid pretreatment respectively.

obtained from untreated SB suggests inaccessibility of the enzymes to cellulose due to the presence of lignin and hemicellulose. The enzymes inaccessibility to cellulose appeared to be drastically reduced via pretreatments, hence the improved cellulose conversion rate obtained from the pretreated SB. On the other hand, enzymatic hydrolysates contained low amount of xylose (Figure 2), which can be attributed to the effectiveness of the acid pretreatment step in hemicellulose removal. Also, the presence of xylose in the hydrolysates may be connected to the action of cellulases and $\beta$-glucosidase enzymes which caused the disruption of lignocellulosic matrix thereby releasing xylose (Guilherme et al., 2015).

\subsection{Fermentation}

Table 5 shows the batch fermentation profile of the $S$. cerevisiae-IQAr/45-1 on enzymatic hydrolysate of two-stage

TABLE 4: Comparison of one-stage $\mathrm{NaOH}$ pretreatment, two-stage $\mathrm{NaOH}+$ maleic acid pretreatment and other pretreatment methods on the yield of fermentable sugars from sugarcane bagasse after enzymatic saccharification.

\begin{tabular}{|c|c|c|c|c|}
\hline Biomass source & Pretreatment conditions & Type of Enzyme cocktail & $\begin{array}{l}\text { Saccharification/ } \\
\text { Conversion rate }\end{array}$ & Reference \\
\hline \multirow{8}{*}{$\begin{array}{l}\text { Sugarcane } \\
\text { bagasse }\end{array}$} & Raw (untreated) & \multirow{3}{*}{$\begin{array}{l}\text { Cellulase }+\beta \text { - glucosidase } \\
\text { (Novozyme 188) }\end{array}$} & $12.9 \%$ & This study \\
\hline & $3 \% \mathrm{NaOH}\left(121^{\circ} \mathrm{C}, 60 \mathrm{~min}\right)$ & & $60.2 \%$ & This study \\
\hline & $\begin{array}{l}\text { Two-stage, } 3 \% \mathrm{NaOH}\left(121^{\circ} \mathrm{C}\right. \\
60 \mathrm{~min})+0.3 \% \text { Maleic acid } \\
\left(121^{\circ} \mathrm{C}, 60 \mathrm{~min}\right)\end{array}$ & & $70.4 \%$ & This study \\
\hline & $\begin{array}{l}1 \% \mathrm{NaOH} \text { at } 600 \mathrm{~W} \text { for } 4 \mathrm{~min} \text {, } \\
\text { microwave }\end{array}$ & Commercial cellulase (Zytex) & $66.5 \%$ & (Binod et al., 2012) \\
\hline & $1 \% \mathrm{NaOH}\left(115^{\circ} \mathrm{C}, 20 \mathrm{~min}\right)$ & Primafast 200 & $38.8 \%$ & (Thite et al., 2019) \\
\hline & $\begin{array}{l}\text { Two-stage, } 1 \% \mathrm{H}_{2} \mathrm{SO}_{4}\left(120^{\circ} \mathrm{C}\right. \\
30 \mathrm{~min})+0.5 \% \mathrm{NaOH}\left(120^{\circ} \mathrm{C}\right. \\
60 \mathrm{~min})\end{array}$ & \multirow[t]{2}{*}{ Cellic CTec2 } & $71.4 \%$ & (Zhang et al., 2018) \\
\hline & $\begin{array}{l}\text { Two-stage, } 1 \% \mathrm{H}_{2} \mathrm{SO}_{4}\left(120^{\circ} \mathrm{C}\right. \\
30 \mathrm{~min})+60 \% \text { ethanol }\left(120^{\circ} \mathrm{C} \text {, }\right. \\
60 \mathrm{~min})\end{array}$ & & $45.9 \%$ & (Zhang et al., 2018) \\
\hline & $1 \% \mathrm{H}_{2} \mathrm{SO}_{4}\left(115^{\circ} \mathrm{C}, 20 \mathrm{~min}\right)$ & Primafast 200 & $25.6 \%$ & (Thite et al., 2019) \\
\hline
\end{tabular}


TABLE 5: Fermentation profile of enzymatic hydrolysate of two-stage $(3.0 \% \mathrm{NaOH}+0.3 \%$ maleic acid) pretreated SB by Saccharomyces cerevisiae (IQAr/45-1 strain) after $30 \mathrm{~h}$.

\begin{tabular}{|c|c|c|c|c|c|c|c|c|}
\hline Time (h) & Glucose $(g / L)$ & Ethanol (g/L) & $Y_{E / S}(g / g)$ & $Q_{P p}(g / L / h)$ & Biomass (g/L) & $Y_{x / s}(g / g)$ & $Q_{P x}(g / L / h)$ & $E_{F}(\%)$ \\
\hline 0 & $17.3 \pm 0.20$ & $0.62 \pm 0.03$ & 0.04 & 0.00 & $0.17 \pm 0.00$ & 0.01 & 0.00 & 0.0 \\
\hline 30 & $0.27 \pm 0.01$ & $8.94 \pm 0.12$ & 0.49 & 0.28 & $8.17 \pm 0.18$ & 0.47 & 0.27 & 95.8 \\
\hline
\end{tabular}

$\mathrm{NaOH}$ and maleic acid pretreated SB after $30 \mathrm{~h}$. Glucose was depleted within $30 \mathrm{~h}$ of fermentation, by this time the ethanol concentration and ethanol yield have reached $8.94 \mathrm{~g} / \mathrm{L}$ and $0.49 \mathrm{~g} / \mathrm{g}$ respectively. Ethanol productivity of $0.28 \mathrm{~g} / \mathrm{L} / \mathrm{h}$ was obtained after $30 \mathrm{~h}$ with the corresponding fermentation efficiency of $95.8 \%$ based on the theoretical ethanol yield. On the other hand, the yeast cell biomass increased to a maximum level of $8.19 \mathrm{~g} / \mathrm{L}$ and biomass yield of 0.47 $\mathrm{g} / \mathrm{g}$ was obtained after $30 \mathrm{~h}$ with productivity of $0.27 \mathrm{~g} / \mathrm{L} / \mathrm{h}$.

High ethanol yield is an indication of efficient conversion of glucose to ethanol by S. cerevisiae -IQAr/45-1. The maximum ethanol yield in this study was higher than those found in many literature reports. For example, de Albuquerque Wanderley and co-workers (2013) reported a maximum ethanol yield of $0.40 \mathrm{~g} / \mathrm{g}$ (equivalent to fermentation efficiency of $78.47 \%$ ) from batch fermentation of enzymatic hydrolysate of delignified SB by S. cerevisiae. Also, Wi et al. (2015) reported ethanol yield of $0.435 \mathrm{~g} / \mathrm{g}$ (equivalent to $85.0 \%$ of the maximum theoretical ethanol yield) from enzymatic hydrolysates of rice straw pretreated with hydrogen peroxide-acetic acid (HPAC) after fermentation by $S$. cerevisiae.

The high biomass yield obtained in this study could be attributed to the presence of yeast extract and peptone in the fermentation media. According to Chang and Webb, (2017), essential elements (nitrogen, phosphorous and vitamins) need to be supplied to the fermentation media as prerequisite to optimize ethanol yield, since hydrolysate from lignocellulosic biomass is generally regarded to be nutrient-deficient (Lau and Dale, 2009).

\section{CONCLUSIONS}

The effect of one-stage $\mathrm{NaOH}$ and two-stage $\mathrm{NaOH}$ and maleic acid pretreatments on cellulose enrichment and enzymatic digestibility of SB were studied. Two-stage $\mathrm{NaOH}$ and maleic acid pretreatment led to $\sim$ two-fold increase in cellulosic fractions from SB. First-stage $\mathrm{NaOH}$ pretreatment efficiently removed lignin fraction, while the second-stage pretreatment with maleic acid efficiently removed hemicellulose fraction. The result of XRD analysis correlated with the changes in the chemical composition of SB as a result of pretreatments.

The presence of low amount of inhibitors in the pretreatment filtrate after the second-stage maleic acid pretreatment highlights the advantage of maleic acid over inorganic acid. Furthermore, two-stage $\mathrm{NaOH}$ and maleic acid pretreatment enhanced the enzymatic digestibility of SB up to $70.4 \%$. The enzymatic hydrolysate was efficiently utilized by $S$. cerevisiae -IQAr/45-1 to produce high yield of ethanol. Thus, optimization of enzymatic hydrolysis at low enzyme loading is expected to further improve the process and reduce cost.

\section{ACKNOWLEDGEMENTS}

Authors thank Coordination of Improvement of Higher Education Personnel (CAPES) and São Paulo Research Foundation (FAPESP) for their financial support.

\section{REFERENCES}

Acharjee, T.C., Jiang, Z.H., Haynes, R.D. and Lee, Y.Y., (2017). Evaluation of chlorine dioxide as a supplementary pretreatment reagent for lignocellulosic biomass. Bioresour Technol. 244, 1049-1054. https://doi.org/10.1016/j.biortech.2017.08.038.

Álvarez, C., Reyes-Sosa, F. M., Díez, B., 2016. Enzymatic hydrolysis of biomass from wood. Microb. Biotechnol. 9, 149-156. https://doi. org/10.1111/1751-7915.12346

Baruah, J., Nath, B. K., Sharma, R., Kumar, S., Deka, R. C., Baruah, D. C., Kalita, E., 2018. Recent trends in the pretreatment of lignocellulosic biomass for value-added products. Front. Energy Res. 6, 141. https://doi.org/10.3389/fenrg.2018.00141.

Binod, P., Satyanagalakshmi, K., Sindhu, R., Janu, K.U., Sukumaran, R.K., Pandey, A., 2012. Short duration microwave assisted pretreatment enhances the enzymatic saccharification and fermentable sugar yield from sugarcane bagasse. Renew energy. 37, 109-116. https:// doi.org/10.1016/j.renene.2011.06.007.

Brienzo, M., Carvalho, A. F. A., de Figueiredo, F. C., de Oliva Neto, P. 2016. Sugarcane bagasse hemicellulose properties, extraction technologies and xylooligosaccharides production. Food waste: Practices, management and challenges, 155-188.

Caputi, A., Ueda, M., \& Brown, T. (1968). Spectrophotometric determination of ethanol in wine. American Journal of Enology and Viticulture, 19(3), 160-165.

Chandel A.K., Antunes, F.A., Anjos, V., Bell, M.J., Rodrigues, L.N., Polikarpov, I., da Silva, S. S., 2014. Multi-scale structural and chemical analysis of sugarcane bagasse in the process of sequential acid-base pretreatment and ethanol production by Scheffersomyces shehatae and Saccharomyces cerevisiae. Biotechnol. Biofuels. 7, 63. https://doi.org/10.1186/1754-6834-7-63.

Chandel, A.K., da Silva, S.S., Carvalho, W., Singh, O.V., 2012. Sugarcane bagasse and leaves: foreseeable biomass of biofuel and bioproducts. J. Chem. Technol. Biotechnol. 87, 11-20. https://doi. org/10.1002/jctb.2742.

Chang, C.W. and Webb, C., 2017. Production of a generic microbial feedstock for lignocellulose biorefineries through sequential bioprocessing. Bioresour. Technol. 227, 35-43. https://doi.org/10.1016/j. biortech.2016.12.055.

de Albuquerque Wanderley, M. C., Martín, C., de Moraes Rocha, G. J., Gouveia, E. R., 2013. Increase in ethanol production from sugarcane bagasse based on combined pretreatments and fed-batch enzymatic hydrolysis. Bioresour. Technol. 128, 448-453. https:// doi.org/10.1016/j.biortech.2012.10.131.

Eberts, T.J., Sample, R.H., Glick, M.R., Ellis, G.H., 1979. A simplified, colorimetric micromethod for xylose in serum or urine, with phloroglucinol. Clin. Chem. 25, 1440-1443.

Girolamo, G. D., Grigatti, M., Bertin, L., Ciavatta, C., Barbanti, L. (2016). Enhanced substrate degradation and methane yield with maleic acid pre-treatments in biomass crops and residues. Biomass Bioenerg. 85, 306-312. http://dx.doi.org/10.1016/j.biombioe.2015.12.029.

Guilherme, A.A., Dantas, P.V.F., Santos, E.S., Fernandes, F.A.N. acedo, G.R., 2015. Evaluation of composition, characterization and enzymatic hydrolysis of pretreated sugar cane bagasse. Braz. J. Chem. Eng. 32, 23-33. https://doi.org/10.1590/ 0104-6632.20150321s00003146.

Isaac, A., de Paula, J., Viana, C.M., Henriques, A.B., Malachias, A., Montoro, L.A., 2018. From nano- to micrometer scale: the role of microwave-assisted acid and alkali pretreatments in the sugarcane biomass structure. Biotechnol. Biofuels. 11, 73-84. https://doi. org/10.1186/s13068-018-1071-6. 
Jönsson, L. J., Martín, C., 2016. Pretreatment of lignocellulose: formation of inhibitory by-products and strategies for minimizing their effects. Bioresour. Technol. 199, 103-112. https://doi.org/10.1016/j. biortech.2015.10.009.

Jung, Y. H., Kim, I. J., Kim, H. K., Kim, K. H. 2014. Whole slurry fermentation of maleic acid-pretreated oil palm empty fruit bunches for ethanol production not necessitating a detoxification process. Bioprocess Biosyst. Eng. 37, 659-665. https://doi.org/10.1007/ s00449-013-1035-y.

Karunarathna, M. S., Smith, R. C., 2020. Valorization of Lignin as a Sustainable Component of Structural Materials and Composites: Advances from 2011 to 2019 . Sustainability. 12, 734-749. https:// doi.org/10.3390/su12020734.

Kucharska, K., Słupek, E., Cieśliński, H., Kamiński, M., 2020. Advantageous conditions of saccharification of lignocellulosic biomass for biofuels generation via fermentation processes. Chemical Papers. 74,1199-1209. https://doi.org/10.1007/s11696-019-00960-1.

Laluce, C., Igbojionu, L.I., Silva, J.L., Ribeiro, C.A., 2019a. Statistical prediction of interactions between low concentrations of inhibitors on yeast cells responses added to the SD-medium at low $\mathrm{pH}$ values. Biotechnol. Biofuels 12,114-124. https://doi.org/10.1186/s13068019-1453-4

Laluce, C., Roldan, I.U., Pecoraro, E., Igbojionu, L.I., Ribeiro, C.A., 2019b. Effects of pretreatment applied to sugarcane bagasse on composition and morphology of cellulosic fractions. Biomass Bioenerg. 126, 231-238. https://doi.org/10.1016/j.biombioe.2019.03.002.

Laluce, C., Morais, M.R., Masiero, M.O.C., Longo, E., 2013. Advantages of using the hybrid strain IQAR/45-1 of Saccharomyces cerevisiae for growth and ethanol production at sub-lethal temperatures. Proc. Int. Soc. Sugar Cane Technol. 28, 356-358.

Lau, M.W., Dale, M.E., 2009. Cellulosic ethanol production from AFEX-treated corn stover using Saccharomyces cerevisiae 424A (LNH-ST). Proc. Natl. Acad. Sci. 106, 1368-1373. https://doi. org/10.1073/pnas.0812364106.

Lee, H. V., Hamid, S. B. A., Zain, S. K., 2014. Conversion of Lignocellulosic Biomass to Nanocellulose: Structure and Chemical Process. Sci. World J. 2014. 1-20. https://doi.org/10.1155/2014/63101.

Li, P., Cai, D., Luo, Z., Qin, P., Chen, C., Wang, Y., et al. 2016. Effect of acid pretreatment on different parts of corn stalk for second generation ethanol production. Bioresour. Technol. 206, 86-92. https:// doi.org/10.1016/j.biortech.2016.01.077

Martinez, A., Rodriguez, M.E., York, S.W., Preston, J.F., Ingram L.O., 2000. Use of UV absorbance to monitor furans in dilute acid hydrolysates of biomass. Biotechnol. Prog. 16, 637-641. https://doi. org/10.1021/bp0000508.

Matsakas L., Nitsos C., Raghavendran V., Yakimenko O., Persson G., Olsson E., Rova U., Olsson L., Christakopoulos P., 2018. A novel hybrid organosolv: steam explosion method for the efficient fractionation and pretreatment of birch biomass. Biotechnol. Biofuels.11,160-169. https://doi.org/10.1186/s13068-018-1163-3.

Mohapatra S., Mishra C., Behera S. S., Thatoi H., 2017. Application of pretreatment, fermentation and molecular techniques for enhancing bioethanol production from grass biomass -A review. Renew. Sustain. Energy Rev. 78, 1007-1032. https://doi.org/10.1016/j. rser.2017.05.026.

Naik S. N., Goud V. V., Rout P. K., Jacobson K., and Dalai A. K., 2010. Characterization of Canadian biomass for alternative renewable biofuel. Renew. Energy. 35, 1624-1631. https://doi.org/10.1016/j. renene.2009.08.033.

Palmowski, L.M., Müller, J.A., 2000. Influence of the size reduction of organic waste on their anaerobic digestion. Water Sci. Technol. 41, 155-162. https://doi.org/10.2166/wst.2000.0067.

Qiao, H., Cui, J., Ouyang, S., Shi, J., Ouyang, J., 2019. Comparison of Dilute Organic Acid Pretreatment and a Comprehensive Exploration of Citric Acid Pretreatment on Corn Cob. J. Renew. Mater. 7, 1197-1207

Rabelo, S.C., Maciel Filho, R., Costa, A.C., 2009. Lime pretreatment of sugarcane bagasse for bioethanol production. Appl. Biochem. Biotechnol. 153, 139-150. https://doi.org/10.1007/s12010-008-8433-7.

Rezende, C. A., de Lima, M. A., Maziero, P., deAzevedo, E. R., Garcia, W., Polikarpov, I., 2011. Chemical and morphological characterization of sugarcane bagasse submitted to a delignification process for enhanced enzymatic digestibility. Biotechnol. Biofuels. 4, 54 . https://doi.org/10.1186/1754-6834-4-54
Rodrigues, F.G., Assunção, R.M.N., Vieira, J.G., Meireles, C.S., Cerqueira, D.A. Barud, H.S, Ribeiro, S.J.L, Messaddeq Y, 2007. Characterization of methylcellulose produced from sugar cane bagasse cellulose: Crystallinity and thermal properties. Polym. Degrad. Stab. 92, 205-210. https://doi.org/10.1016/j.polymdegradstab.2006.11.008.

Rongpipi, S., Ye, D., Gomez, E. D., Gomez, E. W., 2019. Progress and opportunities in the characterization of cellulose-an important regulator of cell wall growth and mechanics. Front. Plant Sci. 9, 18941921. https://doi.org/10.3389/fpls.2018.01894.

Sabanci, K., Buyukkileci, A.Q., 2018. Comparison of liquid hot water, very dilute acid and alkali treatments for enhancing enzymatic digestibility of hazelnut tree pruning residues. Bioresour. Technol. 261,15865. https://doi.org/10.1016/j.biortech.2018.03.136.

Sasmal S., Goud V. V., and Mohanty K., 2012. Characterization of biomasses available in the region of North-East India for production of biofuels. Biomass Bioenerg. 45, 212-220. https://doi. org/10.1016/j.biombioe.2012.06.008.

Segal L., Creely, J.J., Martin, A.E., Conrad C.M., 1959. An empirical method for estimating the degree of crystallinity of native cellulose using the X-ray diffractometer. Text Res. J. 29, 764-786. https://doi.org/10.1177/004051755902901003.

Silveira M.H.L., Morais A.R.C., Lopes A.M.D., Olekszyszen D.N., Bogel-Lukasik R., Andreaus J, Ramos L.P., 2015. Current pretreatment technologies for the development of cellulosic ethanol and biorefineries. Chemsuschem. 8, 3366-90. https://doi.org /10.1002/ cssc. 201500282

Singh S., Cheng G., Sathitsuksanoh S., Wu D., Varanasi P., George A., Balan V., Gao Xi, Kumar R., Dale B.E., Wyman C.E., Simmons B.A. 2015. Comparison of different biomass pretreatment techniques and their impact on chemistry and structure. Front Energy Res. 2, 62-73. https://doi.org/10.3389/fenrg.2014.00062.

Sluiter, A., Hames, B., Ruiz, R., Scarlata, C., Sluiter, J., Templeton, D., Crocker, D., 2008. Determination of structural carbohydrates and lignin in biomass. LAP. 1617, 1-16. NREL/TP-510-42618.

Sporck, D., Reinoso, F.A., Rencoret, J., Gutiérrez, A., José, C., Ferraz, A., Milagres, A.M., 2017. Xylan extraction from pretreated sugarcane bagasse using alkaline and enzymatic approaches. Biotechnol. Biofuels. 10, 296-307. https://doi.org/10.1186/s13068-017-0981-z.

Sun, J.X., Sun, X.F., Sun, R.C., Su, Y.Q., 2004. Fractional extraction and structural characterization of sugarcane bagasse hemicelluloses. Carbohydr. Polym. 56, 195-204. https://doi.org/10.1016/j. carbpol.2004.02.002

Sun, S.L., Sun, S.N., Wen, J.L., Zhang, X.M., Peng, F., Sun, R.C., 2015. Assessment of integrated process based on hydrothermal and alkaline treatments for enzymatic saccharifcation of sweet sorghum stems. Bioresour. Technol. 175, 473-9. https://doi.org/10.1016/j. biortech.2014.10.111.

Thite, V. S., Nerurkar, A. S., 2019. Valorization of sugarcane bagasse by chemical pretreatment and enzyme mediated deconstruction. Scientific reports. 9, 1-14. https://doi.org/10.1038/s41598 019-52347-7.

Timung, R., Naik Deshavath, N., Goud, V. V., Dasu, V. V., 2016. Effect of subsequent dilute acid and enzymatic hydrolysis on reducing sugar production from sugarcane bagasse and spent citronella biomass. J. Energy. 2016, 1-12. https://doi. org/10.1155/2016/8506214.

Wi, S. G., Cho, E. J., Lee, D. S., Lee, S. J., Lee, Y. J., Bae, H. J., 2015. Lignocellulose conversion for biofuel: a new pretreatment greatly improves downstream biocatalytic hydrolysis of various lignocellulosic materials. Biotechnol. Biofuels. 8, 228. https://doi. org/10.1186/s13068-015-0419-4.

Zhang, H., Wei, W., Zhang, J., Huang, S., Xie, J., 2018. Enhancing enzymatic saccharification of sugarcane bagasse by combinatorial pretreatment and Tween 80. Biotechnol. Biofuels. 11, 309-321. https://doi.org/10.1186/s13068-018-1313-7.

Zhang, T., Zheng, Y., Cosgrove, D.J., 2016. Spatial organization of cellulose microfibrils and matrix polysaccharides in primary plant cel walls as imaged by multichannel atomic force microscopy. Plant $\mathrm{J}$. 85, 179-192. https://doi.org/10.1111/tpj.13102.

Zhao, D., Li, Y.R., 2015. Climate change and sugarcane production: potential impact and mitigation strategies. International Journal of Agronomy, 2015. https://doi.org/10.1155/2015/547386.

Zheng, Q., Zhou, T., Wang, Y., Cao, X., Wu, S., Zhao, M., Guan, X 2018. Pretreatment of wheat straw leads to structural changes and improved enzymatic hydrolysis. Sci. Rep. 8, 1-9. https://doi. org/10.1038/s41598-018-19517-5. 